\title{
Pengaruh Penambahan Bacillus subtilis Pada Biodegradasi DDT Oleh Phlebia brevispora
}

\author{
Purnomo, $\mathrm{AS}^{(*)} ;$ Fajriah \\ ${ }^{1}$ Jurusan Kimia, FMIPA Institut Teknologi Sepuluh Nopember \\ Jl. Arief Rahman Hakim, Surabaya 60111 Indonesia \\ *e-mail: adi_setyo@chem.its.ac.id
}

\begin{abstract}
DDT is a pesticide that persistent in the environment and has risk to human health. In this study, the effect of addition of Bacillus subtilis on biodegradation of DDT by Phlebia brevispora was investigated. B. subtilis was added at $1,3,5,7$, and $10 \mathrm{~mL}\left(1 \mathrm{ml} \approx 6,7 \times 10^{8}\right.$ bacteria cell $/ \mathrm{ml}$ culture). The highest degradation of DDT was shown in the addition of $10 \mathrm{~mL}$ of bacteria about $75 \%$ during 7-day incubation, and compared the results of that by P. brevispora without the addition of bacteria was 64\%. DDD, DDE and DDMU were detected as metabolic products. This study indicated that addition of $B$. subtilis can enhance DDT degradation by $P$. brevispora.
\end{abstract}

Keywords : Biodegradation, DDT, Phlebia brevispora, Bacillus subtilis

\begin{abstract}
DDT merupakan pestisida yang bersifat persisten di lingkungan, dan memiliki resiko kesehatan bagi manusia. Pada penelitian ini, pengaruh penambahan bakteri Bacillus subtilis pada biodegradasi DDT oleh jamur Phlebia brevispora telah diteliti. B. subtilis ditambahkan pada volume $1,3,5,7$, dan $10 \mathrm{~mL}\left(1 \mathrm{ml} \approx 6,7 \times 10^{8}\right.$ sel bakteri / $\mathrm{ml}$ kultur $)$. Hasil degradasi DDT oleh $P$. brevispora tanpa penambahan bakteri adalah 64\%. Degradasi tertinggi DDT diperoleh pada penambahan $10 \mathrm{~mL}$ bakteri sekitar 75\% selama masa inkubasi 7 hari. DDD, DDE and DDMU terdeteksi sebagai produk metabolit. Penelitian ini menunjukkan bahwa penambahan $B$. subtilis dapat meningkatkan degradasi DDT oleh P. brevispora.
\end{abstract}

Katakunci : Biodegradasi, DDT, Phlebia brevispora, Bacillus subtilis

\section{Pendahuluan}

Dikloro-difenil-trikloroetana (DDT) merupakan insektisida sintetik pertama yang memiliki peranan penting dalam membasmi nyamuk malaria selama Perang Dunia ke II. Efek DDT sebagai pestisida ditemukan oleh Paul Muller pada tahun 1939, dimana DDT dijuluki bahan kimia ajaib (the wonder chemical), yang menyelamatkan ribuan hektar tanaman dari serangan hama serangga. Akan tetapi, DDT memiliki sifat larut dalam lemak, sehingga residunya terus terbawa dalam rantai makanan dan menumpuk dalam jaringan lemak [1]. Residu DDT dapat menimbulkan masalah kesehatan seperti kanker payudara, gangguan metabolisme hormon, gangguan imunologi, kerusakan DNA dalam sel, dan mampu menurunkan kemampuan reproduksi atau menyebabkan cacat pada janin [2] Residu DDT hingga kini masih ditemukan di lingkungan terutama di lokasi yang dekat dengan aktivitas manusia seperti pelabuhan, dan area pertanian. Mengingat dampak negatif yang ditimbulkan dari DDT, diperlukan suatu metode yang dapat menghilangkan atau mengurangi residu DDT dan produk metabolitnya.

Beberapa metode untuk proses degradasi DDT telah diterapkan, termasuk secara fisikokimia dan biologi. Pada umumnya, proses kimia dan fisika lebih cepat dibandingkan dengan biologi, akan tetapi berdampak pada kondisi tanah dan memerlukan biaya yang relatif tinggi $[3,4]$. 
Biodegradasi merupakan metode paling aman, efisien dan lebih murah dalam mendegradasi beberapa polutan organik dengan menggunakan mikroorganisme (jamur atau bakteri) sebagai agen pendegradasi dengan cara mengubah senyawa tersebut menjadi senyawa yang kurang toksik atau senyawa tidak toksik yang ramah lingkungan $[5,6]$. Salah satu jamur pelapuk putih yang mampu mendegradasi DDT adalah Phlebia brevispora [7]. $P$. brevispora hanya mampu mendegradasi $30 \%$ DDT selama 21 hari masa inkubasi [7], dimana hasil ini relatif rendah dan membutuhkan waktu yang lama, sehingga perlu dilakukan modifikasi kultur yang tepat untuk meningkatkan kemampuan $P$. brevispora dalam mendegradasi DDT.

Salah satu metode untuk mengoptimalkan degradasi DDT oleh jamur adalah dengan penambahan bakteri. Bakteri mampu hidup pada berbagai habitat dan mampu menguraikan senyawa-senyawa kompleks menjadi senyawasenyawa yang lebih sederhana untuk memperoleh zat-zat tertentu yang dibutuhkan dalam rangka mempertahankan hidupnya. Beberapa bakteri tanah telah diketahui mampu mendegradasi senyawa-senyawa polutan dimana salah satunya adalah Bacillus subtilis. B. subtilis dapat medegradasi DDT sebesar $65 \%$ selama 14 hari masa inkubasi dalam kondisi anaerob [8]. Selain itu, B. subtilis juga pernah dilaporkan dapat memproduksi biosurfaktan surfactin $[9,10]$ yang dapat digunakan untuk meningkatkan kelarutan polutan organik. Berdasarkan hal tersebut, penambahan bakteri $B$. subtilis pada kultur jamur $P$. brevispora diharapkan dapat meningkatkan biodegradasi DDT, dimana $B$. subtilis akan memproduksi biosurfaktan untuk meningkatkan kelarutan DDT yang bersifat nonpolar sehingga dapat lebih mudah diakses oleh jamur untuk didegradasi. Selain itu B. subtilis dapat membantu mendegradasi DDT dan produk metabolit yang dihasilkan oleh jamur.

Penggunaan kultur campuran jamur dan bakteri untuk meningkatkan kemampuan degradasi DDT telah dilaporkan sebelumnya. Optimasi degradasi DDT oleh jamur dengan penambahan bakteri telah dilakukan oleh Hermansyah [11], dimana kultur bakteri $B$. subtilis ditambahkan pada kultur jamur Pleurotus ostreatus pada biodegradasi DDT dan diperoleh peningkatan degradasi sebesar $42 \%$ selama 7 hari inkubasi. Peningkatan degradasi DDT oleh jamur Pleurotus eryngii dengan penambahan bakteri $B$. subtilis juga pernah dilaporkan dapat meningkatkan degradasi sebesar $88 \%$ [12]. Selain itu, bakteri B. subtilis juga dapat meningkatkan degradasi DDT oleh jamur pelapuk coklat Daedalea dickinsii dan Fomitopsis pinicola masing-masing sebesar 74\% dan 86\% [13,14]. Berdasarkan uraian diatas, pada penelitian ini diteliti pengaruh penambahan $B$. subtilis pada degradasi DDT oleh jamur P. brevispora.

\section{Metodologi}

\subsection{Alat dan Bahan}

Alat dan instrumentasi yang digunakan pada penelitian ini yaitu: erlenmeyer berpenutup, gelas beker, neraca digital, corong pisah, labu bundar, corong kaca, jarum ose, cawan steril, botol ampul, suntikan (syringe), pompa penyedot, ultrasonic cleaner, evaporator, autoclave, autoshacker, kertas saring Whatman 0,2 $\mu \mathrm{m}$ diameter $110 \mathrm{~mm}$, HPLC terdiri dari pompa Integral PU-1500 (Jasco, Jepang) dan detector UV-Vis MD-1510 (Jasco, Jepang) dilengkapi dengan kolom Inertsil ODS-3 $(150 \mathrm{~mm}$ ) dengan diameter dalam 4,6 mm (GL Science, Jepang). GC/MS dengan system GC HP 6890 (HP, USA) terhubung dengan detektor massselective HP 5973 (HP, USA) dengan kolom DB5MS (30 m, J \&W Scientific, CA, USA).

Bahan-bahan yang digunakan dalam penelitian ini yaitu: jamur $P$. brevispora TMIC34596 dan bakteri B. subtilis NBRC 3009 yang diperoleh dari koleksi jamur Laboratorium Kimia Mikroorganisme Jurusan Kimia FMIPA ITS, DDT, Potato Dextrose Agar (PDA), Potato Dextrose Broth (PDB), Nutrient Borth (NB), Nutrient Agar (NA), aseton, Aqua DM, $\mathrm{Na}_{2} \mathrm{SO}_{4} \cdot \mathrm{xH}_{2} \mathrm{O}, n$-heksana, dimethyl sulfoxide (DMSO), metanol, trifluoro acid (TFA), pirena, DDE, DDD, dan DDMU. Semua bahan-bahan kimia adalah PA grade (99\%) yang didapatkan secara komersil dari PT Mitra Gemilang Surabaya

\subsection{Regenerasi Jamur Phlebia brevispora}

Jamur pelapuk putih dari spesies $P$. brevispora merupakan jamur yang digunakan dalam penelitian ini. Miselium jamur $P$. brevispora diinokulasikan pada medium PDA dalam cawan petri berdiameter $9 \mathrm{~cm}$, dan di pre-inkubasi secara statis pada suhu $30{ }^{\circ} \mathrm{C}$ selama 7 hari.

\subsection{Persiapan Kultur Cair Jamur}

Miselium jamur $P$. brevispora hasil regenerasi (diameter $1 \mathrm{~cm}$ ) diinokulasikan ke dalam labu 
erlenmeyer $100 \mathrm{~mL}$, yang berisi media $10 \mathrm{~mL}$ medium PDB, dengan menggunakan jarum ose secara aseptis, kemudian dipre-inkubasi selama 7 hari pada suhu $30^{\circ} \mathrm{C}$ [15-20].

\subsection{Regenerasi Bakteri}

Pada penelitian ini digunakan bakteri B. subtillis yang diperoleh dari NITE Biological Resource Center (NBRC, Jepang). Masing-masing bakteri diregenerasi dengan cara diinokulasi ke dalam cawan petri yang berisi medium NA dan diinkubasi pada suhu $37^{\circ} \mathrm{C}$ selama 24 jam [21].

\subsection{Persiapan Kultur Cair Bakteri}

Sebanyak 1 koloni bakteri diinokulasikan ke dalam labu erlenmeyer $(100 \mathrm{~mL})$ yang berisi 60 $\mathrm{mL}$ medium NB. Kultur bakteri diinkubasi ke dalam inkubator dengan shaker pada kecepatan $180 \mathrm{rpm}$ dan suhu $37^{\circ} \mathrm{C}$ selama 20 jam.

\subsection{Biodegradasi DDT oleh Jamur pelapuk putih Phlebia brevispora}

Setelah pre-inkubasi selama 7 hari, sebanyak 10 mL PDB medium ditambahkan ke dalam kultur Jamur $P$. brevispora (volume akhir $20 \mathrm{~mL}$ ), dan kemudian ditambahkan $50 \mu \mathrm{L}$ DDT $5 \mathrm{mM}$ dalam DMSO (konsentrasi akhir: 0,25 mmol DDT/labu). Tiap labu diberi oksigen dan ditutup dengan sumbat kaca serta diselotip untuk mencegah penguapan DDT. Kultur diinkubasi secara statis selama 7 hari pada suhu $30^{\circ} \mathrm{C}$. Sebagai kontrol, kultur dinonaktifkan dengan autoclave pada suhu $121^{\circ} \mathrm{C}$ selama 10 menit sebelum ditambah DDT.

\subsection{Biodegradasi DDT oleh Bakteri Bacillus subtilis}

Setelah pre-inkubasi selama 20 jam, kultur bakteri dengan variasi volume $1,3,5,7$, dan 10 $\mathrm{mL}\left(1 \mathrm{ml} \approx 6,7 \times 10^{8}\right.$ sel bakteri / ml kultur $)$ dinokulasikan ke dalam PDB medium (volume total $20 \mathrm{~mL}$ ), dan kemudian ditambahkan $50 \mu \mathrm{L}$ DDT $5 \mathrm{mM}$ dalam DMSO (konsentrasi akhir: 0,25 mmol DDT/labu). Tiap labu diberi oksigen dan ditutup dengan sumbat kaca serta diselotip untuk mencegah penguapan DDT. Kultur diinkubasi secara statis selama 7 hari pada suhu $30^{\circ} \mathrm{C}$. Sebagai kontrol, kultur dinonaktifkan dengan autoclave pada suhu $121^{\circ} \mathrm{C}$ selama 10 menit sebelum ditambah DDT.

\subsection{Penambahan Bakteri Bacillus subtilis pada \\ Biodegradasi DDT oleh Phlebia brevispora}

Setelah pre-inkubasi, B. subtilis diinokulasi pada variasi volume $1,3,5,7$ dan $10 \mathrm{~mL}$ secara terpisah ke dalam $10 \mathrm{~mL}$ kultur P. brevispora, kemudian ditambahkan PDB sampai didapatkan volume akhir $20 \mathrm{~mL}$. Pada masing-masing labu yang berisi kultur campuran jamur dan bakteri ditambahkan $50 \mathrm{~mL}$ DDT $5 \mathrm{mM}$ dalam DMSO (konsentrasi akhir: 0,25 mmol DDT/labu). Tiap labu diberi oksigen dan ditutup sumbat kaca serta diselotip untuk mencegah penguapan DDT. Kultur diinkubasi secara statis selama 7 hari pada suhu $30^{\circ} \mathrm{C}$. Sebagai kontrol negatif, kultur dinonaktifkan dengan autoclave terlebih dahulu pada suhu $121^{\circ} \mathrm{C}$ selama 10 menit sebelum ditambah DDT.

\subsection{Perolehan Ulang (Recovery) DDT dan Identifikasi Produk Metabolit}

Masing-masing kultur hasil inkubasi ditambah $20 \mathrm{~mL}$ metanol dan $50 \mu \mathrm{L}$ pirena $5 \mathrm{mM}$. Sampel dicuci dengan $5 \mathrm{~mL}$ aseton. Kultur disaring menggunakan kertas saring Whatman 41 (GE healthcare life Science, UK) 0,2 $\mu \mathrm{m}$ diameter 110 $\mathrm{mm}$. Filtrat dievaporasi pada suhu $64^{\circ} \mathrm{C}$ dan diekstrak dengan $200 \mathrm{~mL}$ n-heksana. Fasa organik dipisahkan, lalu dikeringkan dengan $\mathrm{Na}_{2} \mathrm{SO}_{4}$ anhidrat, dan kemudian dievaporasi pada suhu $68^{\circ} \mathrm{C}$ hingga tersisa sekitar $1 \mathrm{~mL}$. Konsentrat sampel dianalisis menggunakan GCMS dengan gas pembawa Helium, volume injeksi $1 \mu \mathrm{L}$, aliran spilt $54 \mathrm{~mL} /$ menit, dan suhu oven diatur $80^{\circ} \mathrm{C}$ selama 3 menit, dinaikkan hingga $320^{\circ} \mathrm{C}$, ditahan selama 2 menit dengan kenaikan konstan $20^{\circ} \mathrm{C}$ per menit, kemudian suhu diturunkan menjadi $300^{\circ} \mathrm{C}$ dan ditahan selama 5 menit. Sisa sampel dievaporasi kembali hingga kering dan ditambah 1 $\mathrm{mL}$ metanol. Sampel dihomogenkan dengan ultrasonic cleaner, kemudian dianalisis menggunakan HPLC, dan dielusi dengan $82 \%$ metanol dan $18 \%$ air (1\% TFA) dengan laju alir 1 $\mathrm{ml} / \mathrm{min}[15,22,23]$.

\section{Hasil dan Pembahasan}

\subsection{Penentuan Panjang Gelombang Maksimum dan Pembuatan Kurva Kalibrasi}

$P$. brevispora telah dilaporkan memiliki kemampuan untuk mendegradasi DDT masingmasing sekitar 9\% dan 30\% selama inkubasi 7 dan 21 hari pada media low nitrogen (LN) [7]. Akan tetapi, hasil degradasi tersebut relatif rendah dan membutuhkan waktu inkubasi yang panjang. Oleh karena itu, kemampuan $P$. brevispora dalam mendegradasi DDT perlu ditingkatkan dengan penambahan bakteri $B$. subtilis. Bakteri ini telah dilaporkan sebagai bakteri yang dapat memproduksi biosurfaktan, yang dapat digunakan 
untuk meningkatkan kelarutan zat organik hidrofobik termasuk DDT, untuk mengoptimalkan akses penyerapan oleh jamur [24-26].

Dalam penelitian ini, $P$. brevispora memiliki kemampuan untuk mendegradasi DDT sekitar 64\% selama inkubasi 7 hari dalam media PDB. Dalam penelitian ini, hasil degradasi (64\%) lebih tinggi dibandingkan dengan hasil degradasi yang telah dilaporankan sebelumnya $(9 \%)$ oleh Xiao et al. [7], pada konsentrasi DDT (konsentrasi akhir: $0,25 \mathrm{mmol} \mathrm{DDT} / \mathrm{labu}$ ) dan waktu inkubasi (7 hari) yang sama. Dalam penelitian ini, media PDB digunakan sebagai media P. brevispora, dimana media PDB ini mengandung nutrisi yang lebih lengkap dibandingkan dengan media $\mathrm{LN}$, sehingga $P$. brevispora lebih cocok untuk tumbuh dan dapat mendegradasi DDT yang lebih tinggi. Hasil ini menunjukkan bahwa komposisi media pertumbuhan berpengaruh dalam meningkatkan kemampuan $P$. brevispora untuk mendegradasi DDT.

Hasil dari degradasi DDT oleh B. subtilis ditunjukkan dalam Tabel 1. Bakteri mendegradasi DDT masing-masing sekitar 35\%, 66\%, 80\%, $84 \%$ dan $86 \%$ pada volume $1,3,5,7$, dan $10 \mathrm{~mL}$ bakteri dalam media PDB. Hasil ini menunjukkan bahwa semakin banyak jumlah bakteri $B$. subtilis pada media PDB, semakin tinggi juga jumlah DDT yang terdegradasi. Kantachote et al. [27] telah melaporkan bahwa Bacillus sp. mampu menurunkan DDT oleh $51 \%$ dalam kultur cair selama masa inkubasi 7 hari. Bacillus cereus, Bacillus coagulans, B. subtilis, Escherichia coli dan Enterobacter aerogenes juga dapat mendegradasi DDT [28]. Selain itu, B. subtilis juga telah dilaporkan mampu mendegradasi beberapa polutan organik yang persisten (POPs), termasuk DDT $[8,28,29]$. Hal ini menunjukkan bahwa bakteri $B$. subtilis memiliki kemampuan untuk mendegradasi DDT selain menghasilkan biosurfaktan.

Kemampuan jamur $P$. brevispora mendegradasi DDT dengan penambahan bakteri $B$. subtilis ditunjukkan dalam Tabel 1. Setelah inkubasi selama 7 hari, masing-masing sekitar 56\%, 58\%, $60 \%, 66 \%$ dan $75 \%$ dari DDT terdegradasi oleh campuran kultur jamur dan bakteri dengan penambahan bakteri pada $1,3,5,7$, dan $10 \mathrm{~mL}$ (Tabel. 1). Hasil ini menunjukkan bahwa penambahan bakteri $B$. subtilis dapat meningkatan degradasi DDT oleh P. brevispora. Hai et al. [30] melaporkan bahwa kultur campuran bakteri dari lumpur dan jamur pelapuk putih Coriolus versicolor bisa menghilangkan pestisida aldicarb, atrazin, dan alachlor masing-masing sebesar $82 \%$, $77 \%$, dan $67 \%$ setelah diinkuasi selama 7 hari. Selain itu, kultur campuran jamur-bakteri juga dapat menghilangkan pirena lebih tinggi (67\%), dibandingkan dengan kultur campuran jamurjamur $(39 \%)$ dan campuran bakteri-bakteri $(56 \%)$ selama inkubasi 28 hari, serta dalam degradasi fenantrena dan fluorantena [31]. Data ini menunjukkan bahwa kultur campuran jamurbakteri bisa menurunkan polutan organik secara efektif.

Penambahan B. subtilis dalam kultur jamur $P$. brevispora memiliki pengaruh yang berbeda-beda pada proses degradasi DDT. Degradasi DDT oleh $P$. brevispora meningkat pada penambahan 7 dan $10 \mathrm{~mL}$ bakteri $B$. subtilis, sedangkan pada penambahan 1 , 3 dan $5 \mathrm{~mL}$, mengakibatkan penurunan jumlah degradasi DDT karena bakteri tidak cukup untuk menghasilkan biosurfaktan. Penambahan $10 \mathrm{ml}$ bakteri $B$. subtilis pada kultur jamur $P$. brevispora menghasilkan degradasi paling tinggi sekitar $75 \%$. B. subtilis menghasilkan biosurfaktan lipopeptida yang meningkatkan kelarutan zat non-polar [24,32].

\subsection{Identifikasi Produk Metbolit}

Identifikasi produk metabolit dari DDT oleh $P$. brevispora, B. subtilis dan kultur campuran, dianalisa menggunakan GCMC dengan membandingkan waktu retensi dan spektrum massa. Pada $P$. brevispora, produk metabolit dari DDT teridentifikasi antara lain DDD (1,1-dikloro 2,2-bis (4-klorofenil) etana), DDE (1,1-dikloro 2,2-bis (4-klorofenil) etilen ) dan DDMU (1chloro 2,2-bis (4-klorofenil) etana) (data tidak ditampilkan). Xiao et al. [7] telah melaporkan bahwa $P$. brevispora mendegradasi DDT menjadi DDD, dan kemudian mengkonversi DDD menjadi 2,2-bis (4-klorofenil) asam asetat (DDA) dan kemudian diikuti menjadi 4,4-diklorobenzofenon (DBP) dan 4,4 -diklorobenzihidrol (DBH) selama masa inkubasi 21 hari. Dalam studi ini, DDD juga terdeteksi sebagai metabolit utama, selain DDE dan DDMU. Metabolit ini mungkin dihasilkan selama degradasi awal, yang kemudian diubah menjadi metabolit seperti dilaporkan oleh Xiao et al. [7]. DDMU dihasilkan dari reduktif deklorinasi reduktif DDD atau dehidroklorinasi dari DDE. Dalam kasus $B$. subtilis, metabolit DDT diidentifikasi seperti DDD dan DDMU (data tidak ditampilkan). DDD juga terdeteksi sebagai 
metabolit utama, dimana DDMU dihasilkan dari redukti deklorinasi dari DDD.

Pada kultur campuran $P$. brevispora dengan penambahan $B$. subtilis, metabolit DDT teridentifikasi seperti DDD, DDE dan DDMU. Kromatogram produk metabolit DDT ditunjukkan pada Gambar. 1, dimana pirena digunakan sebagai standar internal. Puncak dari pirena, DDD, DDE, dan DDMU memiliki waktu retensi masingmasing $11,7,13,4,12,2$ dan 11,3 menit, yang memiliki m/z masing-masing 202, 235, 246, 212. Hasil ini menunjukkan bahwa produk metabolit dari DDT oleh kultur campuran adalah produk metabolit DDT oleh $P$. brevispora tanpa penambahan bakteri. Hal ini menunjukkan bahwa $P$. brevispora merupakan biota utama pada degradasi DDT oleh kultur campuran jamurbakteri. B. subtilis mungkin mendukung pada produksi biosurfaktan untuk meningkatkan degradasi DDT bukan untuk mendegradasi DDT itu sendiri. Akan tetapi, penyelidikan tentang jalur degradasi DDT oleh kultur campuran jamurbakteri memerlukan penyelidikan lebih lanjut.

Tabel 1. Degradasi DDT oleh jamur $P$. brevispora, bakteri $B$. subtilis dan kultur campuran dalam media PDB selama inkubasi 7 hari.

\begin{tabular}{|l|c|c|}
\hline \multirow{2}{*}{ Volume B. subtilis (mL) } & \multicolumn{2}{|c|}{ Degradasi DDT (\%) } \\
\cline { 2 - 3 } & \multicolumn{2}{|c|}{$64.25 \pm 3.86$} \\
\hline (hanya P. brevispora) & $35.38 \pm 6.36$ & $55.73 \pm 0.19$ \\
\hline 1 & $66.21 \pm 0.64$ & $57.84 \pm 0.98$ \\
\hline 3 & $79.51 \pm 0.04$ & $59.89 \pm 0.27$ \\
\hline 5 & $84.06 \pm 1.76$ & $66.35 \pm 1.31$ \\
\hline 7 & $86.44 \pm 1.64$ & $75.00 \pm 0.01$ \\
\hline 10 & &
\end{tabular}

Analisa dilakukan menggunakan HPLC. Data merupakan rata-rata \pm standard deviasi $(\mathrm{n}=3) .1 \mathrm{~mL}$ bakteri setara dengan $6.7 \times 10^{8}$ sel bakteri $/ \mathrm{mL}$ kultur.

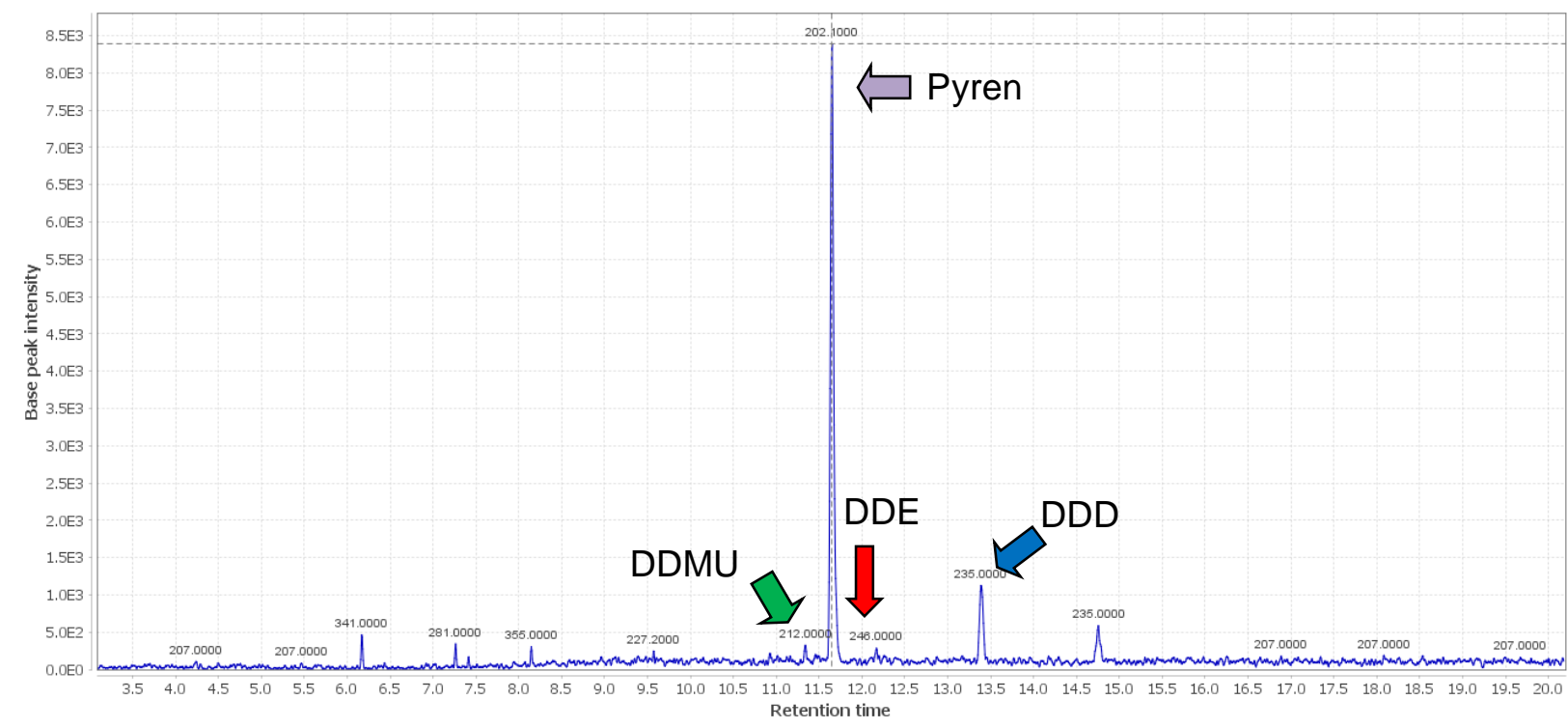

Gambar 1. Kromatogram hasil degradasi DDT oleh kultur campuran P. brevispora dan B. subtilis 
Jamur pelapuk putih termasuk beberapa spesies Phlebia merupakan jamur yang dapat menghasilkan ekstraselular enzim ligninolitik seperti lakase, MnP dan LiP, yang bertanggung jawab untuk mendegradasi lignin serta polutan [33-36]. Namun, keterlibatan enzim ini dalam degradasi DDT belum diketahui. Selain itu, enzim intraseluler mungkin terlibat dalam degradasi DDT, yang salah satunya adalah sitokrom P450 monooksigenase (P450). Enzim P450 mengkatalisis berbagai reaksi seperti hidroksilasi, oksidasi, reduksi, dehalogenasi, dan dehidrogenasi. P450 terlibat dalam degradasi beberapa polutan [37-43]. Dalam kondisi aerobik, DDT dimetabolisme menjadi DDD, dicofol dan 2,2-bis (4-klorofenil) asam asetat (DDA) oleh P450 [44,45], dimana DDT monohydroxylation dari cincin aromatik dengan P450 diusulkan sebagai jalur metabolisme baru DDT biodegradasi [46]. Hal ini diasumsikan bahwa baik enzim ekstraselular ligninolitik dan enzim intraselular P450 memiliki peran penting dalam metabolisme DDT.

\section{Kesimpulan}

Penambahan bakteri $B$. subtilis dapat meningkatkan degradasi DDT oleh $P$. brevispora selama masa inkubasi 7 hari, dimana penambahan $10 \mathrm{~mL} \mathrm{~B}$. subtilis menunjukkan degradasi DDT tertinggi (75\%). DDD, DDE dan DDMU terdeteksi sebagai produk metabolik. Penelitian menunjukkan bahwa $B$. subtilis dapat digunakan untuk meningkatkan degradasi DDT oleh $P$. brevispora.

\section{Ucapan Terimakasih}

Penulis berterima kasih kepada Prof. Ichiro Kamei, dari University of Miyazaki yang telah membantu dalam penyedian instrumen HPLC dan GCMS. Penelitian ini dibiayai dari hibah penelitian skem Penelitian Unggulan Perguruan Tinggi (PUPT) 2016 No: 01714 / IT2.11 / PN.08 / 2016, dari Direktorat Jenderal Penguatan Penelitian dan Pengembangan, Kementerian Riset, Teknologi dan Pendidikan Tinggi, Indonesia.

\section{Daftar Pustaka}

[1] World Health Organization, "Environmental Health Criteria 9: DDT and its derivatives," WHO, Geneva, 1979.
[2] M. A. Dalvie, "DDT: Health Effects. University of Cape Town, Cape Town, South Africa." Elsevier, 2011.

[3] R. Boussahel, D. Harik, M. Mammar and S. Lamara-Mohamed, "Degradation of obsoletes DDT by Fenton oxidation with zero-valent iron." Desalination, vol. 206(1), 2007, pp. 369-372.

[4] R. Borello, C. Minero, E. Pramauro, E. Pelizzetti, N. Serpone, and H. Hidaka, "Photocatalytic degradation of DDT mediated in aqueous semiconductor slurries by simulated sunlight." Environ. Toxicol. Chem., vol. 8(11), 1989. pp. 997-1002.

[5] J. Bumpus, D. D. Focht, M. Alexander, and S. D. Aust, "Biodegradation of DDT (1,1,1 trikloro-2,2bis (4-klorofenil) etane) by "Phanerochaete chrysosporium." Chemosphere, vol. 19, 1985, Issues 8-9.

[6] J. M. Aislabie, N. K. Richards, and H. L. Boul, "Microbial degradation of DDT and its residues - a review." NZJ. Agricul. Res., vol. 40(2), 1997, pp. 269-282.

[7] P. Xiao, T. Mori, I. Kamei, and R. Kondo, "A novel metabolic pathway for biodegradation of DDT by the white rot fungi, Phlebia lindtneri and Phlebia brevispora." Biodegradation, vol. 22(5), 2011, pp. 859-867.

[8] B. T. Johnson, and J. O. Kennedy, "Biomagnification of p,p'-DDT and methoxychlor by bacteria." Appl. Microbiol., vol. 26, 1973, pp. 66-71.

[9] N. Awasthi, A. Kumar, R. Makkar, and S. Cameotra, "Enhanced biodegradation of endosulfan, a chlorinated pesticide in presence of a biosurfactant." J. Environ. Sci. Health B, vol. 34, 1999, pp. 793-803.

[10] C. N. Mulligan, "Environmental application for biosurfactans." Environ. J., vol. 133(2), 2005, pp. 183-198.

[11] F. T. Hermansyah, "Optimasi degradasi DDT oleh Pleurotus ostreatus dengan penambahan bakteri Bacillus subtilis", Skripsi, Institut Teknologi Sepuluh November, Surabaya, 2014.

[12] D. Lestari, "Pengaruh penambahan bakteri Bacillus subtilis terhadap biodegradasi DDT oleh jamur pelapuk putih Pleurotus eryngii", Skripsi, Institut Teknologi Sepuluh November, Surabaya, 2016.

[13] H. D. Rizqi, "Pengaruh penambahan bakteri terhadap biodegradasi DDT oleh Daedalea dickinsii", Tesis, Institut Teknologi Sepuluh November, Surabaya, 2016.

[14] A. Sariwati, "Pengaruh penambahan bakteri terhadap biodegradasi DDT oleh jamur pelapuk coklat Fomitopsis pinicola", Tesis, Institut Teknologi Sepuluh November, Surabaya, 2016.

[15] A. S. Purnomo, I. Kamei, and R. Kondo, "Degradation of 1,1,1-trichlro-2,2-bis (4- 
chlorophenyl) ethane (DDT) by brown-rot fungi." J. Biosci. Bioeng., vol. 105 (6), 2008, pp. 614-621.

[16] A. S. Purnomo, F. Koyama, T. Mori, and R. Kondo, "DDT degradation potential of cattle manure compost." Chemosphere, vol. 80 (6), 2010, pp. 619-624.

[17] A. S. Purnomo, T. Mori, I. Kamei, T. Nishii, and R. Kondo, "Application of mushroom waste medium from Pleurotus ostreatus for bioremediation of DDT-contaminated soil." Inter. Biodet. Biodeg., vol. 64 (5), 2010, pp. 397-402.

[18] A. S. Purnomo, T. Mori, and R. Kondo, "Involvement of Fenton reaction in DDT degradation by brown-rot fungi." Inter. Biodet. Biodeg., vol. 64 (7), 2010, pp. 560-565.

[19] A. S. Purnomo, T. Mori, K. Takagi, and R. Kondo, "Bioremediation of DDT contaminated soil using brown-rot fungi." Inter. Biodet. Biodeg., vol. 65 (5), 2011, pp. 691-695.

[20] A. S. Purnomo, T. Mori, I. Kamei, and R. Kondo, "Basic studies and applications on bioremediation of DDT: A review." Inter. Biodet. Biodeg., vol. 65 (7), 2011, pp. 921-930.

[21] S. Wahyuni, M. T. Suhartono, A. Khaeruni, A. S.Purnomo, Asranudin, Holilah, P. A. Riupassa, "Purification and Characterization of Thermostable Chitinase from Bacillus SW41 for Chitin Oligomer Production." Asian J. Chem., vol. 28(12), 2016, pp. 2731-2736.

[22] A. S. Purnomo, T. Mori, S. R. Putra, and R. Kondo, R. "Biotransformation of heptachlor and heptachlor epoxide by white-rot fungus Pleurotus ostreatus." Inter. Biodet. Biodeg., vol. 82, 2013, pp. 40-44.

[23] A. S. Purnomo, S. R. Putra, K. Shimizu, and R. Kondo, "Biodegradation of heptachlor and heptachlor epoxide-contaminated soils by whiterot fungal inocula." Environ. Sci. Poll. Res., vol. 21, 2014, pp. 11305-11312.

[24] N. Pornsunthorntawee, N. Arttaweeporn, S. Paisanjit, P. Somboonthanate, M. Abe, R. Rujiravanit, and S. Chavadej, "Isolation and comparison of biosurfactants produced by Bacillus subtilis $\mathrm{Pt} 2$ and Pseudomonas aeruginosa SP4 for microbial surfactantenhanced oil recovery.” Biochem. Eng. J., vol. 42, 2008, pp. 172-179.

[25] E. J. Gudiña, V. Rangarajan, R. Sen, and L. R. Rodrigues, "Potential therapeutic applications of biosurfactants." Trends Pharmac. Sci., vol. 34, 2013, pp. 667-675.

[26] R. Zouari, S. E. Chaabouni, and D. G. Aydi, "Optimization of Bacillus subtilis SPB1 biosurfactant production under solid-state fermentation using by-products of a traditional olive mill factory.” Achiev. Life Sci., vol. 8, 2014, pp. 162-169.
[27] D. Kantachote, I. Singleton, N. McClure, R. Naidu, M. Megharaj, and B. D. Harch, "DDT resistance and transformation by different microbial strains isolated from DDTcontaminated soils and compost materials." Compost Sci. Utiliz., vol. 11 (4), 2003, pp. 300310.

[28] B. E. Langlois, J. A. Collins, and K. G. Sides, "Some factors affecting degradation of organochlorine pesticide by bacteria." J. Dairy Sci., vol. 53, 1970, pp. 1671-1675.

[29] R. Bidlan, "Studies on DDT degradation by bacterial strains." PhD Thesis, Central Food Technological Research Institute, University of Mysore, India, 2003.

[30] F. I. Hai, O. Modin, K. Yamamoto, K. Fukushi, F. Nakajima, and L. D. Nghiem, "Pesticide removal by a mixed culture of bacteria and white-rot fungi.” J. Taiwan Inst. Chem. Eng., vol. 43, 2012, pp. 459-462.

[31] S. Wang, N. Nomura, T. Nakajima, and H. Uchiyama, "Case study of the relationship between fungi and bacteria associated with highmolecular-weight polycyclic aromatic hydrocarbon degradation.” J. Biosci. Bioeng., vol. 113 (5), 2012, pp. 624-630.

[32] F. A. Bezza, and E. M. N. Chirwa, "Production and applications of lipopeptide biosurfactant for bioremediation and oil recovery by Bacillus subtilis CN2.” Biochem. Eng. J., vol. 101, 2015, pp. 168-178.

[33] J. A. Buswell, Y. J. Cai, and S. T. Chang, "Fungal-and substrate- associated factors affecting the ability of individual mushroom species to utilize different lignocellulosic growth substrates." In: S. Chang, J. A. Buswell, and S. Chiu, (Eds.), Mushroom Biology and Mushroom Products. The Chinese Univ. Press, Hong Kong, 1993, pp. 141-150.

[34] M. Hofrichter, T. Lundell, and A. Hatakka, "Conversion of milled pine wood by manganese peroxidase from Phlebia radiata." Appl. Environ. Microbiol., vol. 67, 2001, pp. 4588-4593

[35] T. Vares, M. Kalsi, and A. Hatakka, "Lignin peroxidases, manganese peroxidases, and other ligninolytic enzymes produced by Phlebia radiata during solid-state fermentation of wheat straw. Appl. Environ. Microbiol., vol. 61, 1995, pp. 3515-3520.

[36] A. A. Leontievsky, T. Vares, P. Lankinen, J. K. Shergill, N. N. Pozdnyakova, N. M. Myasoedova, N. Kalkkinen, L. A. Golovleva, R. Cammack, C. F. Thurston, and A. Hatakka, "Blue and yellow laccases of ligninolytic fungi." FEMS Microb. Lett., vol. 156, 1997, pp. 9-14

[37] S. Masaphy, D. Levanon, Y. Henis, K. Venkateswarlu, and S. L. Kelly, "Evidence for cytochrome P-450 and P-450-mediated 
benzo(a)pyrene hydroxylation in the white rot fungus Phanerochaete chrysosporium." FEMS Microbiol. Lett., vol. 135, 1996, pp. 51-55.

[38] L. Bezalel, Y. Hadar, P. P. Fu, J. P. Freeman, and C. E. Cerniglia, "Initial oxidation products in the metabolism of pyrene, anthracene, fluorene, and dibenzothiophene by the white rot fungus Pleurotus ostreatus." Appl. Environ. Microbiol., vol. 62, 1996, pp. 2554-2559.

[39] I. Kamei, and R. Kondo, "Biotransformation of dichloro-, trichloro-, and tetrachlorodibenzo-pdioxin by the white-rot fungus Phlebia lindtneri." Appl. Microbiol. Biotech., vol. 68, 2005, pp. 560566.

[40] I. Kamei, S. Sonoki, K. Haraguchi, and R. Kondo, "Fungal bioconversion of toxic polychlorinated biphenyls by white-rot fungus," Phlebia brevispora. Appl. Microbiol. Biotech., vol. 73, 2006, pp. 932-940.

[41] T. Mori, and R. Kondo, "Oxidation of chlorinated dibenzo-p-dioxin and dibenzofuran by white-rot fungus, Phlebia lindtneri." FEMS Microbiol. Lett., vol. 216, 2002, pp. 223-227.

[42] T. Mori, K. Nakamura, and R. Kondo, "Fungal hydroxylation of polychlorinated naphthalenes with chlorine migration by wood rotting fungi." Chemosphere, vol. 77, 2009, pp. 1230-1235.

[43] N. Hiratsuka, H. Wariishi, and H. Tanaka, "Degradation of diphenyl ether herbicides by the lignin-degrading basidiomycete Coriolus Versicolor." Appl. Microbiol. Biotech., vol. 57, 2001, pp. 563-571.

[44] A. Cùany, M. Pralavorio, D. Pauron, J. B. Berge, D. Fournier, and C. Blais, "Characterization of microsomal oxidative activities in a wild-type and in a DDT resistant strain of Drosophila melanogaster." Pestic. Biochem. Physiol., vol. 37, 1990, pp. 293-302.

[45] N. Joußen, D. G. Heckel, M. Haas, I. Schuphan, and B. Schmidt, "Metabolism of imidacloprid and DDT by P450 CYP6G1 expressed in cell cultures of Nicotiana tabacum suggests detoxification of these insecticides in Cyp6g1-overexpressing strains of Drosophila melanogaster, leading to resistance." Pest Manag. Sci., vol. 64, 2008, pp. 65-73.

[46] H. Suhara, A. Adachi, I. Kamei, and N. Maekawa, "Degradation of chlorinated pesticide DDT by litter-decomposing basidiomycetes." Biodegradation, vol. 22, pp. 1075-1086. 